p-ISSN 2746-0312

e-ISSN 2745-522x

https://ojs.umrah.ac.id/index.php/juliet

\title{
The Students' Willingness and Learning Attitudes Toward Speaking Skill
}

\author{
${ }^{1}$ Angelika Rouli Sinaga ${ }^{2}$ Satria Agust, ${ }^{3}$ Muhammad Candra \\ ${ }^{1}$ English Language Education Study Program, Universitas Maritim Raja Ali Haji, \\ Tanjungpinang, Indonesia \\ ${ }^{2}$ English Language Education Study Program, Universitas Maritim Raja Ali Haji, \\ Tanjungpinang, Indonesia \\ ${ }^{3}$ English Language Education Study Program, Universitas Maritim Raja Ali Haji, \\ Tanjungpinang, Indonesia \\ Corresponding email: angelsnga2@gmail.com
}

Received August 19, 2021; Revised September 5, 2021; Published September 13, 2021

https://doi.org/10.31629/juliet.v2i2.3647

\begin{abstract}
The purpose of this research was to find out whether or not there was a correlation between the students' willingness to communicate, and learning attitudes toward speaking skill. This research used a quantitative correlation to find the relationship between the variables. This study's population consisted of 147 students. The purposive sampling method was used to obtain the sample for this study, which consisted of 25 students from XI IPS 2 and XI IPS 3 class. The instruments used to obtain data were questionnaires and online test. The questionnaire utilized a google form with 10 questions and five answers for each questions to assess students' willingness to communicate, and learning attitudes. second, test was used to obtain the results of each student's speaking skill, which were recorded. Normality test, homogeneity test, linearity test, bivariate test, multiple correlation equation, and hypothesis test were used to analyze data. Based on data analysis, the multiple regression equation obtained was 1.14, implying that there was a very significant relationship between willingness to communicate, and learning attitudes toward speaking skills.
\end{abstract}

Keywords: Student's willingness, Learning attitudes, Speaking skill, Correlation research.

\section{INTRODUCTION}

Almost all countries in the world now use the English language. Therefore, it could be said that English is an international language. Nowadays, we could see technology, such as cellphones, laptops, or other electronic items, that the settings are in English. However, in Indonesia, English is still a foreign language, so we learn more about it because English is an important language today. English has four skills; speaking, reading, listening, and writing. Now in this paper, the writer would like to explain speaking skills first. Speaking is the important one in English skills. According to Bashir, Azeem, and Dogar (2011), by talking, it 
would give much benefits. Oral communication would help students to improve their speaking skills.

There are some problems with students who do not want to speak up or show their ideas, opinions, and feelings in speaking. The first problem is willingness to communicate. When learning a foreign language, lack of speaking can result in an ineffective learning process. As a result, it is true that the concept of Willingness to Communicate (WTC), which is described as the purpose and desire to initiate communication, is important in learning a second or foreign language (MacIntyre, Clément, Dörnyei, \& Noels, 1998).

Secondly, these attitudes are student's internal issues, that they will solve if they have willingness to learn a foreign language. However, vice versa, they would have problem if they don't have motivation to learn it. According to Abidin et al (2012), students' ability to learn a second language is affected not just by their mental abilities or language skills, but also by their behaviors and perceptions of the target language.

Based on the researcher's experience during teaching and learning process in SMA Negeri 1 Toapaya, the researcher found that the students were not interested in learning English. For example, when the teacher taught them, they just accepted what the teacher explained without questioning the lesson during the learning process. That is why the researcher was interested in finding out if there was any correlation between willingness to communicate and learning attitudes toward students' speaking skills.

\section{METHOD}

Quantitative research, according to Creswell (2014), is a method for examining the relationship between variables to test objective hypotheses. These variables might be calculated using an instrument in most cases. As a result, statistical methods may be used to analyze the data. Therefore, this study would employ a correlation research design. The study of the relationship between two naturally occurring variables is known as correlation analysis (Richard,2013). A correlational study design assesses the relationship between two variables without the researcher needs to manipulate one of them. It aims to determine if there is any correlation between the variables.

According to the definition, there were three variables in this research. The variables consisted of two independent variables and one dependent variable. The independent variables were willingness to communicate (x1), learning attitudes (x2), and then the dependent variable was students' speaking skill (y). The researcher used SPSS.23 to find out the results.

\section{RESULT}

This research was conducted at eleventh grade students in SMA Negeri 1 Toapaya, located in JL. Gesek KM 25 Kawal, Toapaya Asri, Kecamatan Toapaya, Kabupaten Bintan, Provinsi. Kepulauan Riau.This research was conducted in April 2021.

First, student's willingness to communicate were 50 respondents collected via a google form and the results of the questionnaire was on the third category "Neutral". Second was learning attitudes. The results of this variable was on the second category "Disagree". And the last was speaking test. The researcher invited 2 raters to help her to calculate the test and the results was "Very Strong". 
JULIET, September 2021; $\operatorname{Vol}(2)$ No(2): 77 - 81

p-ISSN 2746-0312

e-ISSN 2745-522x

Tests of Normality

\begin{tabular}{l|r|r|r|r|r|r} 
& \multicolumn{3}{c}{ Kolmogorov-Smirnoxa } & \multicolumn{3}{c}{ Shapiro-Wilk } \\
& Statistic & \multicolumn{1}{c}{ df } & \multicolumn{1}{c}{ Sig. } & Statistic & \multicolumn{1}{c}{ df } & \multicolumn{1}{c}{ Sig. } \\
\hline Willingness & .105 & 50 & $.200^{\circ}$ & .968 & 50 & .200 \\
\hline Learning Attitudes & .117 & 50 & .083 & .976 & 50 & .384 \\
\hline Speaking Score & .074 & 50 & $.200^{\circ}$ & .981 & 50 & .578 \\
\hline
\end{tabular}

Figure 1 Normality test table.

The researcher was used Kolmogrov- Smirnov to assess the amount of normality for all variables, and the data were normally distributed because higher than 0.05 . It could be seen from table above, that the value of willingness to communicate was $0.200>0.05$, and the value of learning attitudes was $0.83>0.05$, and the value of speaking was $0.200>0.05$.

The homogeneity test was used to determine whether or not the data came from the same variance. To put it another way, homogeneity meant that all of the data we looked at had the same characteristics. The researcher employed the Levene's test to collect the data. The test's results were as follows:

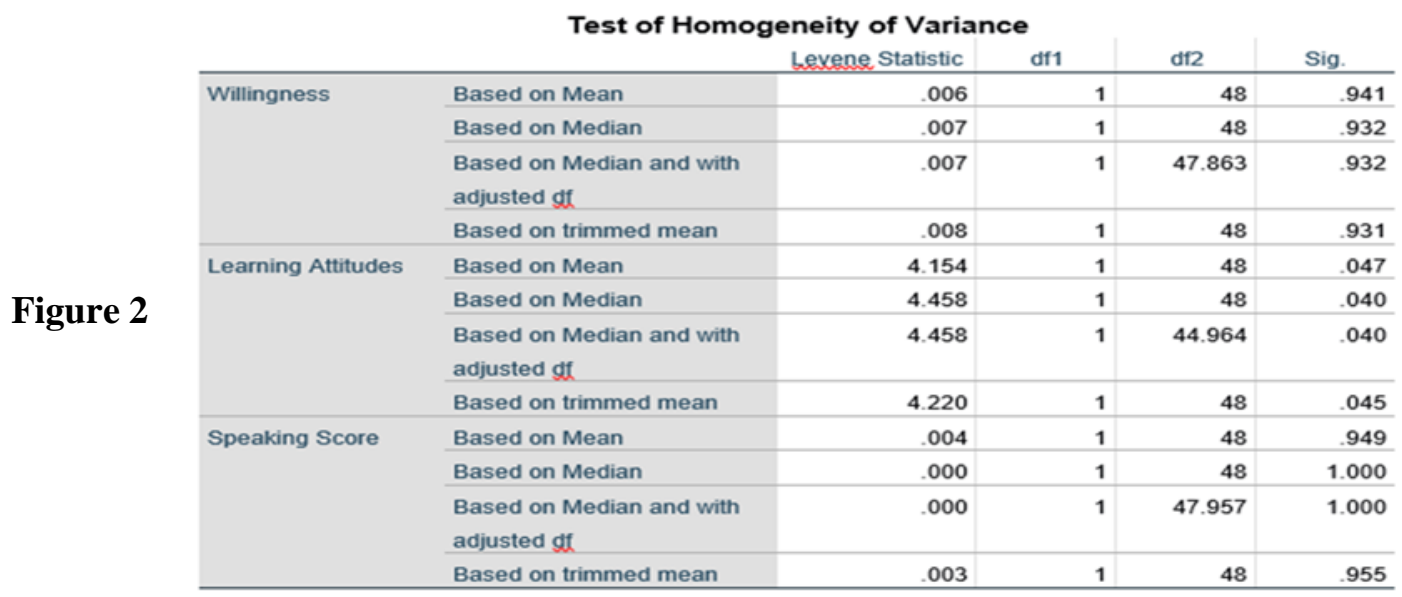

\section{Homogeneity test table}

The significant value of willingness to communicate was $0.941>0.05$, the significant value of learning attitudes was $0.931>0.05$ and the last, the significant value of speaking score was $0.949>0.05$. It could be concluded that the data were homogeneous.

The test results for each variable were shown below the first due to willingness linearity: From the table above, that significant (sig) value of the willingness was 0.812 which was higher than 0.05 , meaning that there was a linear correlation or could be said there was a correlation between $\mathrm{x} 1$ (willingness), $\mathrm{x} 2$ (learning attitudes) and $\mathrm{y}$ (speaking).it could be concluded that there was a linear correlation between willingness to communicate and speaking. 


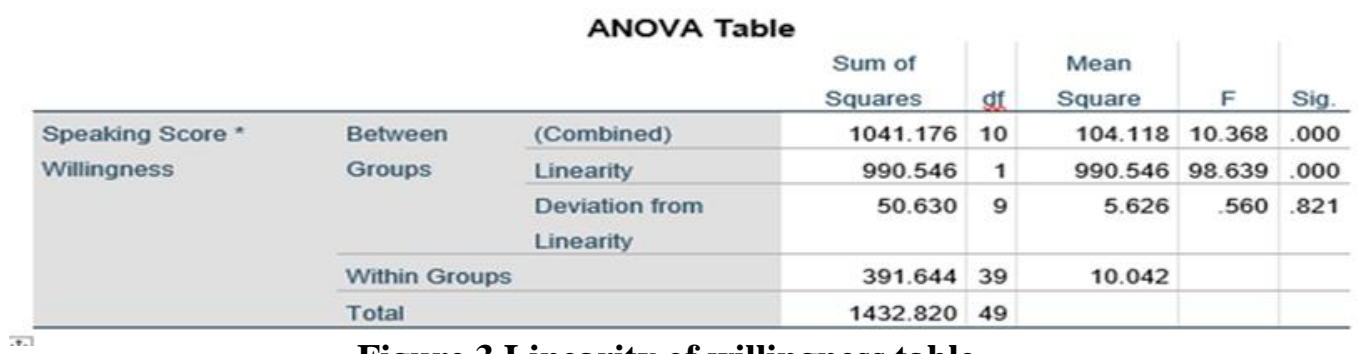

Figure 3 Linearity of willingness table

Next, the linear correlation from learning attitudes, the significant result was 0.979. It meant higher than 0.05 , so the data of learning attitudes was linear. If sig of deviation from linearity was higher than 0.05 , it meant that there was linear correlation but if sig deviation from linearity lower than 0.05 , it meant that there was no correlation. It was shown in the table below:

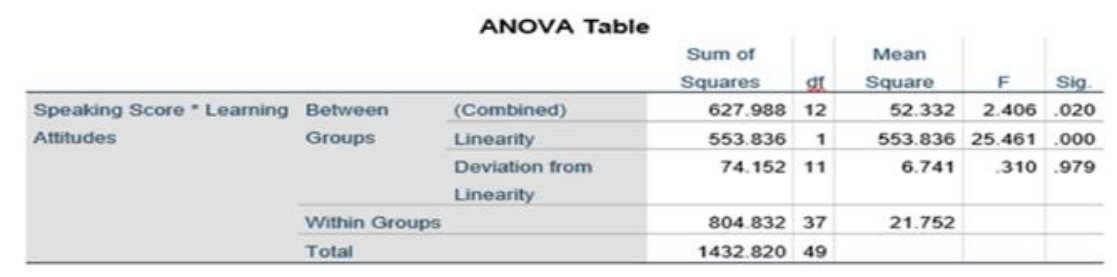

Figure 4 Linearity of learning attitudes table

The researcher conducted the hypotheses test to determine whether the hypothesis was accepted or not. The researcher used the Paired sample test, the correlation between two sets of data to measure how closely they were related.

\section{Figure 5 Hypothesis table}

\begin{tabular}{|c|c|c|c|c|c|c|c|c|c|}
\hline \multicolumn{10}{|c|}{ Paired Samples Test } \\
\hline & & \multicolumn{5}{|c|}{ Paired Differences } & \multirow[b]{3}{*}{$\mathrm{t}$} & \multirow[b]{3}{*}{ df } & \multirow{3}{*}{$\begin{array}{l}\text { Sig. (2- } \\
\text { tailed) }\end{array}$} \\
\hline & & \multirow[b]{2}{*}{ Mean } & \multirow{2}{*}{$\begin{array}{c}\text { Std. } \\
\text { Deviation }\end{array}$} & \multirow{2}{*}{$\begin{array}{c}\text { Std. Error } \\
\text { Mean }\end{array}$} & \multicolumn{2}{|c|}{$\begin{array}{l}95 \% \text { Confidence Interval } \\
\text { of the Difference }\end{array}$} & & & \\
\hline & & & & & Lower & Upper & & & \\
\hline $\begin{array}{l}\text { Pair } \\
1\end{array}$ & $\begin{array}{l}\text { Speaking Score - } \\
\text { Willingness }\end{array}$ & 39.100 & 3.547 & .502 & 38.092 & 40.108 & 77.946 & 49 & .000 \\
\hline $\begin{array}{l}\text { Pair } \\
2\end{array}$ & $\begin{array}{l}\text { Speaking Score - } \\
\text { Learning Attitudes }\end{array}$ & 37.300 & 4.311 & .610 & 36.075 & 38.525 & 61.186 & 49 & .000 \\
\hline
\end{tabular}

\section{DISCUSSION}

From the result of this research, it could be seen that there was a very strong correlation between students' willingness, and learning attitudes toward speaking skill. Each variable showed different result and its category was very strong. This finding was similar to the finding of Knell (2012) who studied the roles of motivation, affective attitudes and willingness to communicate among chines students in early English immersion program. She found that there was a correlation between willingness, and attitudes in the higher levels.

From the result of willingness to communicate, it could be seen in the strong correlation levels between speaking skill, the researcher used questionnaire for showing the results. The questionnaire is given to class XI IPS 2 and XI IPS 3 as the subject of this study. The result was 
similar with the results from Latifah (2020) investigating the factors influencing students' willingness to communicate in English on the higher category.

From the result of learning attitudes, it could be seen in the low category of correlation between speaking skill in class XI IPS 2 and XI IPS 3 to find out the result the researcher used questionnaire by using google form consisting of 10 questions and 3 categories of the questions. Before giving the questionnaire, the researcher explained the direction how to fulfill the questionnaire so that all the students could work on it well. This result was similar with the findings of Azizifar (2020) stating EFL adult learner's attitudes toward learning speaking on the low category and the respondents of this research had negative attitudes toward learning process an English language.

\section{CONCLUSION}

The purpose of this research was to see if there was a correlation between students' willingness to communicate and learning attitudes toward speaking skill in SMA Negeri 1 Toapaya eleventh-grade students. The association was discovered by using a quantitative, namely correlation design in this study. The alternative hypothesis was supported based on the data analysis, which revealed that there was a very strong relationship between students' willingness to communicate and learning attitudes toward speaking skill among eleventh- grade students.

\section{REFERENCES}

Abdin, e. a. (2012). a study of factors affecting EFL. Research gate, 10-30.

Askurny, N. R. (2020). The Correlation Between students' motivation and students' English achievment. umrah.ac.id.

Azizifar, A. (2020). The relationship between attitude and speaking proficiency of Iranian EFL learners: The case of Darrehshehr city. ScienceDirect, 240-247.

Bashir, A. a. (2011). An Analysis of Factors Influencing Learners' English Speaking Skill. 3442.

Creswell, J. W. (2014). Research Design: Qualitative, Quantitative, and Mixed Methods Approaches. Los Angeles: SAGE Publications.

Macintyre, P. N. (1998). Conceptualizing Willingness to Communicate in an L2: A Situational Model of L2 Confidence and Affiliation. The Modern Language Journal, , 545-562.

Richards. (2013). Longman Dictionary of Language Teaching and Applied Linguistics. Longman.

Knell, E. (2012). The Roles of Motiv The Roles of Motivation, Aff ation, Affective Attitudes, and Willingness $t$ ttitudes, and Willingness to Communicate Among Chinese Students in

Latifah, Z. (2020). INVESTIGATING THE FACTORS INFLUENCING STUDENTS' WILLINGNESS TO COMMUNICATE IN ENGLISH. ISLLAC : Journal of Intensive Studies on Language, Literature, Art, and Culture, 91-100.Early English . International Education, 66-87. 